\title{
Ossified costal cartilage during rhinoplasty: A surgical dilemma
}

\author{
Sir, \\ With reference to our paper "Namaste (counterbalancing) \\ technique: Overcoming warping in costal cartilage", \\ published in the last issue of IJPS, the authors have \\ received many communications, a few appreciations and \\ a few queries. There is one which needs to be discussed \\ on this forum.
}

There have been some queries regarding management in a scenario when, during rhinoplasty, the hitherto oblivious surgeon stumbles upon costal cartilage, which is partly ossified. It is a problem which every rhinoplasty surgeon faces time and again during the course of his/her practice. The authors too have had a few patients with ossified cartilages.

Calcification of costal cartilages is unique in that it continues throughout adult life and is in the nature of true ossification. It is considered to be a physiological response of the connective tissue to the biomechanical strains owing to the assumption of an upright posture. ${ }^{[1]}$ According to Kampen et al. ${ }^{[2]}$ the onset of mineralization occurs at the end of puberty directly beneath the perichondrium and increases with age. Premature calcification may be related to endocrine 
disorders such as hyperthyroidism, corticosteroid intake, adrenogenital syndrome or may be a normal variant. ${ }^{|3|}$

Ossification of cartilage has been found to be inversely proportional to the degree of consequent warping in the graft, ${ }^{[4,5]}$ implying that if a cartilage is completely ossified, there will be no warping and hence, the need to use the counterbalancing technique does not arise.

It is when the cartilage is partly ossified that we are faced with the daunting task of carving the hard cartilage while also managing the warping. It is like having the worst of both worlds.

If only dorsal strut is required then the harvested cartilage block can be carved like a bone, using cutting disk and/ or osteotome. The problem arises when one needs it for preparing various grafts. It is difficult but not impossible to cut this ossified cartilage into slices. Usually thick slices are obtained, which can be made thinner with round or diamond burr. Thinning with the burr also makes the grafts softer, malleable and more amenable to carving. Sometimes difficulty might be faced in passing the suture needle through these pieces. In such situations, a 20 -gauge or 22-gauge hypodermic needle can be first passed and then the needle of the suture can be fed into the bevel of the hollow needle so that it can be pulled out from the other side. Slight straightening of the curved needle goes a long way in making things simpler.

Thus, we see that ossified cartilage is not at all contraindicated for use in rhinoplasty surgery. It only requires slight modification of technique and equivalent results are achievable irrespective of the status of ossification of the harvested cartilage.

\section{Financial support and sponsorship}

Nil.

\section{Conflicts of interest}

There are no conflicts of interest.

\section{Kapil S. Agrawal, Raghav Shrotriya}

Department of Plastic Surgery, King Edward Memorial Hospital, Mumbai, Maharashtra, India

Address for correspondence: Dr. Kapil S. Agrawal, Department of Plastic Surgery, Gynec. Wing, $2^{\text {nd }}$ Floor, King Edward Memorial Hospital, Parel, Mumbai - 400 012, Maharashtra, India. E-mail: kapilps@rediffmail.com

\section{REFERENCES}

1. King JB. Calcification of the costal cartilage. Brit $\mathrm{J}$ Radiol 1939;12:2-12.

2. Kampen $\mathrm{WU}$, Claassen $\mathrm{H}$, Kirsoh $\mathrm{T}$. Mineralization and osteogenesis in the human first rib cartilage. Ann Anat 1995; 177:171-7.

3. Rhomberg W, Schuster A. Premature calcifications of costal cartilages: A new perspective. Radiol Res Pract 2014;2014:523405.

4. Balaji SM. Costal cartilage nasal augmentation rhinoplasty: Study on warping. Ann Maxillofac Surg 2013;3: 20-4.

5. Lau AG, Kindig MW, Kent RW. Morphology, distribution, mineral density and volume fraction of human calcified costal cartilage. Acta Biomater 2011;7:1202-9.

This is an open access article distributed under the terms of the Creative Commons Attribution-NonCommercial-ShareAlike 3.0 License, which allows others to remix, tweak, and build upon the work non-commercially, as long as the author is credited and the new creations are licensed under the identical terms.

\begin{tabular}{|l|l|}
\hline \multicolumn{2}{|c|}{ Access this article online } \\
\hline Quick Response Code: & Website: \\
\hline
\end{tabular}

How to cite this article: Agrawal KS, Shrotriya R. Ossified costal cartilage during rhinoplasty: A surgical dilemma. Indian J Plast Surg 2015;48:327-8. 